原著

\title{
高脂血症治療薬による日本人の虚血性心疾患の 予防効果とリスク
}

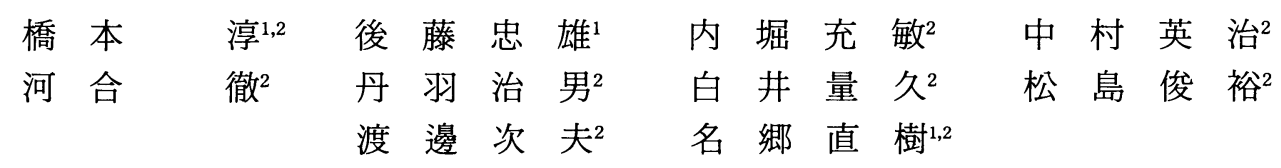

はじめに

ライフスタイルの西欧化に伴って, 本邦においても高コ レステロール血症患者が増加しており，その対応の重要性 が高まっている，高コレステロール血症は虚血性心疾患の 危険因子であり，欧米では高脂血症治療薬が虚血性心疾患 の罹患率・死亡率を低下させるという大規模臨床比較試験 が行われている。近年は，本邦においてもよく使用されて いるスタチン系薬剤の大規模臨床比較試験の結果も報告さ れている ${ }^{1-4)}$. しかし, 高コレステロール血症患者全体に対 する虚血性心疾患の予防効果は，虚血性心疾患の罹患率に よって大きく変化する．日本における虚血性心疾患の罹患 率は欧米の $1 / 5 \sim 1 / 10$ とされており，日本人における高コ レステロール血症のリスクと治療効果は，欧米とは大きく 異なっている可能性がある.

一方, 血清コレステロール值と総死亡の関係について は，血清コレステロール值が高い群だけでなく，低い群に おいても死亡率が高くなっており，その関係は U 型5)であ る。また，血清コレステロール值は，脳出血の罹患率ある いは死亡率と負の相関があり ${ }^{6)}$, 諸外国と比較して脳出血 の多いわが国においては，むしろ低コレステロール血症が より大きなリスクである可能性もある.

虚血性心疾患発症のリスクが低く, 疾病構造も異なるわ が国においては, 高脂血症治療薬の効果は, 欧米と比較し て相対的に低いと考えられるため，薬物療法の実施にあ たっては薬剤の効果が有害性を上回るかどうかを検討する 必要がある。しかし，これまでの研究では，日本人のよう な虚血性心疾患の罹患率が低い対象者に対する薬物療法の

\section{${ }^{1}$ 自治医科大学地域医療学教室}

2 愛知県臨床疫学研究会

原稿受取日：1998 年 5 月 21 日

採用決定日：1998 年 8 月 19 日

効果は証明されておらず，現状では欧米で行われた臨床試 験の結果と日本人の疫学デー夕を基に, 薬物療法の有効性 を検討することが必要である.

そこで今回われわれは, Evidence-based Medicine $(\mathrm{EBM})^{7)}$ の手法を用いて，これまでに行われたスタチン系 薬剤による介入研究と, 日本人の虚血性心疾患の罹患率, 高コレステロール血症のリスクについて情報を収集し，以 下の 2 点について検討を行った。 (1) 日本人の高コレステ ロール血症患者に対する薬物療法の効果を, 虚血性心疾患 の発症を一人予防するための治療必要数 Number Needed to Treat $(\mathrm{NNT})^{8)}$ として算出し, 欧米のデータと比較する. (2) 高コレステロール血症に対する薬物療法が総死亡に与 える影響を日本人の罹患率において推測する.

I. 方 法

高コレステロール血症患者に対する薬物療法が虚血性 心疾患の罹患率, 全体の死亡率に与える影響について検討 するためのデー夕, 日本人の虚血性心疾患の罹患率に関す るデータの収集を行った。

1) 高コレステロール血症患者に対する薬物療法の効果 情報収集を行うポイントを明確にするため, EBMの手

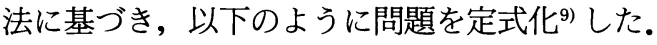

・対象者 (Patient) 高コレステロール血症患者

-介入 (Exposure) 高脂血症治療薬の投与

- 転帰 (Outcome) 虚血性心疾患の罹患率，死亡率の減 少, 全死亡率の変化

上記の疑問の解決のため Cochrane Library ${ }^{10)}$, および MEDLINE を検索した. 検索式には以下の Medical Subject Headings (MeSH) を用いた。

(1) exp ANTICHOLESTEREMIC-AGENTS or exp HYPERLIPIDEMIA/drug-therapy

(2) exp MYOCARDIAL-INFARCTION or exp 
CORONARY-DISEASE or exp MORTALITY

(3) RANDOMIZED CONTROLLED TRIAL in PT or META-ANALYSIS in PT

(4) (1) and (2) and (3)

\section{2) 日本人の虚血性心疾患の罹患率}

日本人の虚血性心疾患の罹患率に関する論文は以下の MeSH を用いて MEDLINE の検索をした。

(1) exp MYOCARDIAL INFARCTION

(2) exp MORBIDITY

(3) JAPAN*

(4) (1) and (2) and (3)

あわせて関連する雑誌 (Japanese Circulation Journal, Journal of Epidemiology, 日本公衆衛生雑誌, 日本循環器管 理研究協議会雑誌) のハンドサーチを行った。

\section{3) 治療必要数の算出法}

治療効果の指標としては, Relative Risk (RR) や Relative Risk Reduction (RRR) がよく用いられるが,これらは治療 群とコントロール群の治療効果の比で罹患率を考慮してい ない. Absolute Risk Reduction (ARR) は，両群の罹患率 の差をとったもので，一人治療した場合にその人が罹患す るリスクをどれほど下げるかということを表わしている。 治療必要数 Number needed to Treat (NNT) はARRの逆 数で，何人治療すると一人の罹患が防げるかという指標と なる ${ }^{8}$.

NNT の算出にあたっては，実際の日本人の高コレステ ロール血症患者に対する一次予防の介入試験のデータがな いため, 欧米で行われた一次予防の介入試験 (WOSCOPS) の結果から得られた冠動脈疾患予防効果 (RR, RRR) と, 日本人の虚血性心疾患の罹患率 (IR) 加ら，以 下の式により計算した。

$$
\begin{aligned}
& A R R=I R-I R \times R R=I R \times R R R \\
& N N T=1 / A R R
\end{aligned}
$$

\section{4）情報の選択基準}

4-1 高コレステロール血症患者に対する薬物療法の効 果

高コレステロール血症に対して，現在もっとも使用され ているスタチン系薬剤を中心に検討することにした。検索 などから得られた文献のなかから，「高コレステロール血 症の治療を行うと虚血性心疾患, あるいは死亡率が減少す るか」という疑問の解決に適切な論文で，以下の条件に合 致するものを選択した。

(1) ランダム化比較試験

(2) スタチン系薬剤による介入

(3) endpoint が虚血性心疾患の発症または死亡

4-2 日本人の虚血性心疾患の罹患率デー夕の選択基準

日本人の虚血性心疾患の罹患率については, いくつかの
観察研究がみつかったが，これらの結果を網羅した総説 ${ }^{11}$ があり, 高コレステロール血症患者全体の治療必要数の算 出には，そのデー夕を用いて検討した。また，年齢別の治 療必要数の算出にあたっては，年齢別および血清コレステ ロールレベル別の冠動脈疾患罹患率の記載がある Hiroshima-Nagasaki Study ${ }^{12)}$ の結果を基に検討した。

4-3 総死亡率の検討のための論文の選択基準

血清コレステロール值と総死亡率の変化は観察研究と 介入研究の結果から検討した。論文は以下の条件に合致す るものを選択した。

（1）血清コレステロールレベル別の死亡率を検討した 観察研究の総説

（2）日本人の血清コレステロールレベル別の死亡率を 検討した観察研究

（3） 総死亡を endpoint とした介入研究のメタアナリシ ス

\section{II. 結 果}

1）高コレステロール血症患者に対する薬物療法の効果 前述の基準をみたした高コレステロール血症患者に対 する介入試験の結果を表にまとめた (Table 1).

選択された論文

(1) 一次予防試験

- WOS-COPS ${ }^{21}$

心筋梗塞の既往のない高コレステロール血症 (平均 LDL-C $192 \mathrm{mg} / \mathrm{dl}$ ) の男性患者を対象に，pravastatinの一 次予防効果を調べた介入試験で，心筋梗塞の発症を primary endpoint にしている. 平均 4.9 年の試験期間で虚血性 心疾患は $31 \%$, 冠動脈疾患による死亡も $32 \%$ 減少し, 薬剤 による一次予防の効果が認められた。

\section{- AFCAPS/TexCAPS ${ }^{4)}$}

冠動脈疾患の既往のない平均的な血清コレステロール 值 (平均 TC $221 \mathrm{mg} / \mathrm{dl}$, LDL-C $150 \mathrm{mg} / \mathrm{dl}$ ) で, 血清 HDL コレステロールの低い (平均 HDL-C 男性 $36 \mathrm{mg} / \mathrm{dl}$, 女性 $40 \mathrm{mg} / \mathrm{dl}$ ) 患者を対象として, lovastatin の一次予防効果を 調べた。平均 5.2 年の試験期間で虚血性心疾患は $37 \%$ 減少 したが， lovastatin 群では心血管疾患以外の死亡がコント ロール群の 1.2 倍あり，総死亡には差を認めなかった (placebo 群/lovastatin 群=77/80).

(2) 二次予防試験

- 4S study ${ }^{1)}$

冠動脈疾患をもつ高コレステロール血症 (平均 TC 259 $\mathrm{mg} / \mathrm{dl}$, LDL-C $187 \mathrm{mg} / \mathrm{dl}$ ) の成人患者 4,444人を対象に, simvastatin の二次予防効果を調べた介入試験で，総死亡を primary endpoint にしている. 平均 5.4 年の試験期間で, 虚 血性心疾患は $34 \%$, 冠動脈疾患による死亡も $26 \%$ 減少し 
Table 1 Selected trials of cholesterol lowering using statin drugs.

\begin{tabular}{|c|c|c|c|c|}
\hline & \multicolumn{2}{|c|}{ Primary Prevention } & \multicolumn{2}{|c|}{ Secondary Prevention } \\
\hline & $\begin{array}{c}\text { WOS-COPS } \\
(1995)\end{array}$ & $\begin{array}{c}\text { AFCAPS/TexCAPS } \\
(1998)\end{array}$ & $\begin{array}{c}4 \mathrm{~S} \\
(1994)\end{array}$ & $\begin{array}{l}\text { CARE } \\
(1996)\end{array}$ \\
\hline No. randomized & 6,595 & 6,650 & 4,444 & 4,159 \\
\hline Age $(y)$ & $45-64$ & $\begin{array}{l}\text { Men } 45-73 \\
\text { Femele } 55-73\end{array}$ & $35-70$ & $21-75$ \\
\hline Male (\%) & 100 & 85 & 81 & 86 \\
\hline Drug & pravastatin & lovastatin & simvastatin & pravastatin \\
\hline Mean Follow up (y) & 4.9 & 5.2 & 5.4 & 5.0 \\
\hline Relative Risk for CHD & $\begin{array}{c}0.69 \\
(0.57-0.83)\end{array}$ & $\begin{array}{c}0.63 \\
(0.50-0.79)\end{array}$ & $\begin{array}{c}0.66 \\
(0.59-0.74)\end{array}$ & $\begin{array}{c}0.76 \\
(0.64-0.91)\end{array}$ \\
\hline Relative Risk for All Death & $\begin{array}{c}0.78 \\
(0.60-1.00) \\
\end{array}$ & 1.05 & $\begin{array}{c}0.70 \\
(0.58-0.85) \\
\end{array}$ & $\begin{array}{c}0.91 \\
(0.74-1.12) \\
\end{array}$ \\
\hline Control group & & & & \\
\hline $\begin{array}{l}\text { CHD Incidence } \\
(/ 1,000 \text { person-year })\end{array}$ & 18.6 & 10.9 & 51.9 & 26.4 \\
\hline CHD Death/All Death (\%) & 45.2 & 19.5 & 73.8 & 60.7 \\
\hline
\end{tabular}

た。これまで薬剤による高コレステロール血症の介入試験 では，虚血性心疾患は減少しても総死亡が増加するという 報告13)もあったが，4S studyではじめて総死亡率も低下 (30\%) することが確認された。

\section{- $\mathrm{CARE}^{3)}$}

冠動脈疾患の既往のある平均的なコレステロール值 (平 均 LDL-C $139 \mathrm{mg} / \mathrm{dl}$ ) の成人患者を対象として, pravastatin の二次予防効果を調べた。平均 5.0 年の試験期間で, 虚 血性心疾患は $24 \%$ 減少したが, LDL-C $125 \mathrm{mg} / \mathrm{dl}$ 以下の群 では, 虚血性心疾患の発症に差はなかった。 また，pravastatin群に乳癌の発生が有意に多かった (placebo 群/ pravastatin 群 $=1 / 12, p=0.002$ ).

いずれの試験においても，スタチン系薬剤の投与によ り, 虚血性心疾患の発症が減少し,これまで議論のあった 総死亡の増加も認められていない. しかし, 試験の対象者 に注目すると，多くが中高年の男性を対象としたものであ り, 試験対象者の虚血性心疾患の罹患率は, 一次予防で あっても，高コレステロール血症患者を対象にした WOSCOPS で 18.6 人 $/ 1,000$ 人年, 平均的な血清コレステロール レベルの患者を対象にした AFCAPS/TexCAPS でも 10.9 人 1,000 人年であり, 日本人と比較して非常に高率である. また, 総死亡について有意差がでた $4 \mathrm{~S}$ study も, 全死亡に 対する冠動脈死の割合が $73.8 \%$ と, 虚血性心疾患が対象者 の主要な死因であり，わが国の状況とはかなり異なってい る.

\section{2）日本の虚血性心疾患の罹患率}

1996 年に Tanaka らがまとめた日本人の虚血性心疾患の 罹患率 ${ }^{11}$ は, 中年男性で $0.57 / 1,000$ 人年 $(0.12-2.56)$, 女性 で $0.15 / 1,000$ 人年 $(0.00-1.52)$ であり, 24 時間以内の突然 死は, 男性で $0.42 / 1,000$ 人年 $(0.00-1.58)$, 女性で $0.09 / 1,000$
人年 $(0.00-0.76)$ である. 北欧, 米国の虚血性心疾患の罹患 率が $5.76 / 1,000$ 人年 (3.74-13.1) であるため, 日本人の虚血 性心疾患の罹患率は，男性でも北欧，米国の $1 / 5$ 以下であ る. 血清コレステロール值が $220 \mathrm{mg} / \mathrm{dl}$ になると虚血性心 疾患の relative risk が 1.5 倍, $240 \mathrm{mg} / \mathrm{dl}$ では 2 倍 ${ }^{14)}$ になる が，虚血性心疾患と突然死をあわせた䍜患率は，血清コレ ステロール值が $240 \mathrm{mg} / \mathrm{dl}$ で, 中年男性で $1.98 / 1,000$ 人年, 女性で $0.48 / 1,000$ 人年である.

3）日本人の高コレステロール血症患者における一次予 防の治療必要数の算出

WOS-COPS は pravastatin による一次予防の介入試験で あり, 冠動脈疾患の RRR は $31 \%, N N T$ は 41.7 人 $/ 5$ 年であ る (41.7 人の患者を 5 年治療すると虚血性心疾患の発症が 1 人減少する). 先に述べたように血清コレステロール值 $240 \mathrm{mg} / \mathrm{dl}$ の日本人の虚血性心疾患の罹患率は，中年男性 で $1.98 / 1,000$ 人年, 女性で $0.48 / 1,000$ 人年と考えられるが, WOS-COPS と同様に pravastatin の投与で冠動脈疾患の発 症が $31 \%$ 低下したと仮定すると, 冠動脈疾患予防の NNT は, 男性で 376 人 $/ 5$ 年, 女性では 1,550 人 $/ 5$ 年となる.

Hiroshima-Nagasaki Study ${ }^{12)}$ の年齢別および血清コレス テロールレベル別の冠動脈疾患罹患率を基に，血清コレス テロール值 $240 \mathrm{mg} / \mathrm{dl}$ 以上の年齢別冠動脈疾患罹患率を計 算した. 高コレステロール血症の虚血性心疾患に対する危 険因子としての強さは，従来の報告 ${ }^{15)}$ からすると若年ほど 強く，高歯になるほど影響は弱くなると考えられるが，そ の影響を定量的に評価するための確たるデータがないた め, 年齢別の相対危険は一定として年齢別冠動脈疾患䍜患 率を計算した。この年齢別罹患率から，スタチン系薬㓮の 投与で冠動脈疾患の発症が $31 \%$ 低下したと仮定して NNT を計算し，その関係をグラフに示した (Fig. 1)。これによる 


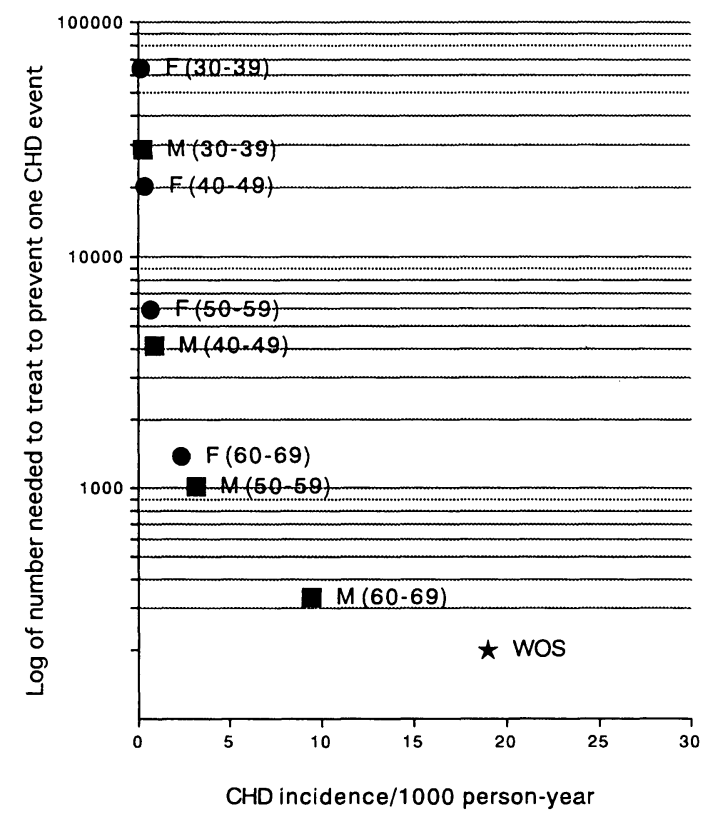

Fig. 1 Relation between CHD incidence and Number Needed to Treat to prevent one CHD event.

と冠動脈疾患の罹患率が小さくなるにつれて NNT は急激 に増加しており，罹患率が低い対象者においては，高コレ ステロール血症の治療により予防できる虚血性心疾患の絶 対数は非常に小さいことがわかる。

\section{4) 日本人における総死亡に対する高コレステロール血 症治療の影響の推則}

\section{4-1 観察研究から}

大規模なコホート研究の結果，高コレステロール血症は 虚血性心疾患発症の危険因子であることが明らかになっ た. しかし，総死亡率に注目すると，血清コレステロール 值が高い群だけでなく，低い群においても死亡率が高く なっており，血清コレステロール值と総死亡率の関係は U 型になっている.

1990 年の National Heart, Lung, and Blood Institute (NHLBI) Conference で, 米国, 欧州, イスラエル，日本で 行われた 19 のコホート研究の結果に基づき, 血清コレステ ロール値と総死亡率の関係について検討5)された。総死亡 率と血清コレステロール值の関係は, 男性ではU 型で, 女 性では水平型となっており (Fig. 2), 虚血性心疾患による 死亡との間には正の相関が認められたが，ある種の癌，呼 吸器疾患, 消化器疾患, 外傷, その他の原因による死亡に は負の相関が認められた。基礎疾患により血清コレステ ロール值が低下している因果の逆転の影響を除くため, 観 察開始 5 年以内の死亡を解析対象から除いても，この傾向 は変わらなかった。

1994 年に Iso らは，40-69 歳の男女 12,187 人を平均 8.9

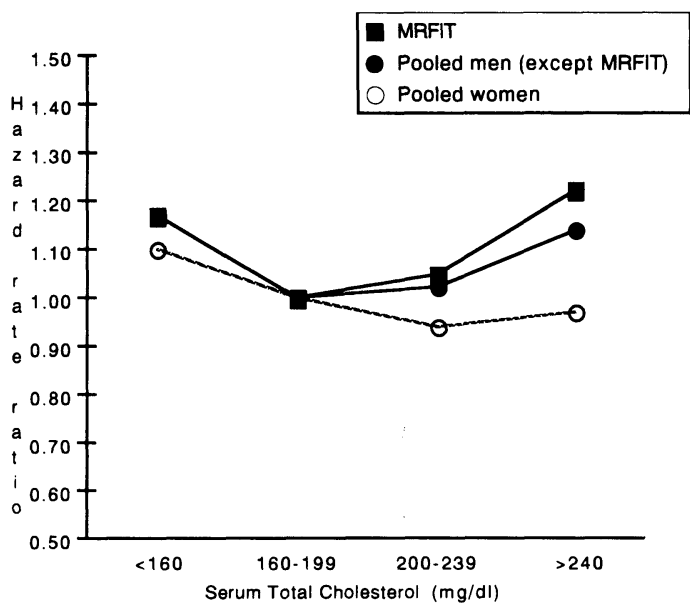

Fig. 2 Graph of pooled and Multiple Risk factor Intervention Trial (MRFIT) estimates of adjusted hazard rate rations in all deaths occurring at least 5 years after baseline in men and women aged 35-69 years without coronary heart disease at baseline. ${ }^{5)}$

年追跡し，血清コレステロール值と総死亡および癌死亡の

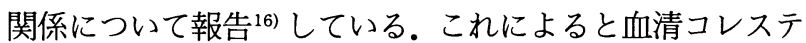
ロール值 $160 \mathrm{mg} / \mathrm{dl}$ 以下の群は, 血清コレステロール值 180-199 mg/dl の群に対して, 総死亡が男性で 1.46 倍, 女性 で 1.69 倍になっている.しかし，血清コレステロール值が $220 \mathrm{mg} / \mathrm{dl}$ 以上の群の総死亡は, 男性で 1.10 倍, 女性では 0.9 倍であり，女性ではむしろ減少している．また，この傾 向は，同様に追跡をはじめて 5 年以内に死亡した対象者を 除いて解析を行っても変わらなかった.

\section{4-2 介入研究の結果から}

総死亡を endpoint とした高脂血症治療薬による介入研 究のメタアナリシスは 6 文献あり 17-22)，そのなかで (1) スタチン系薬剤の総死亡に対する効果，(2) 虚血性心疾患 の罹患率が低い対象者に対する高脂血症治療薬の投与が総 死亡に与える影響，について評価している論文を検討し た。

スタチン系薬剤による介入試験のメタアナリシスでは, 介入により総死亡も減少し，また癌，心血管疾患以外の死 亡との関連も認められなかった ${ }^{211}$. また，従来の治療法と 比較して効果的で安全であるとの報告もある221. しかし, スタチン系薬剤による個々の試験を検討すると，一般的な 日本人の高コレステロール血症患者と比較して, 虚血性心 疾患のリスクが非常に高い対象者に対する試験であるた め，低リスク者へのスタチン系薬剤の投与が，治療による 副作用を上回る効果があるかどうかの結論は出せない.

Smith ら ${ }^{18)}$ は，高コレステロール血症患者に対する介入 試験のうち，6 カ月以上追跡された 35 の研究についてメ夕 アナリシスを行い，対象者の虚血性心疾患のリスクにより 
サブグループに分け報告している．薬剤としてはスタチン 系以外の薬剤による介入試験が大部分であるが，対象者の 虚血性心疾患の死亡率によって 3 群に分けて検討してお り，1,000人年あたり虚血性心疾患の死亡が 50 人以上の High risk 群では, 治療により総死亡も低下 (ORs 0.74 95\% CI，0.60-0.92) がしたが，1,000人年あたり 10-50人の medium risk 群では 0.96 (CI, 0.84-1.09) と差がなく, 1,000 人年あたり 10 人未満の Low risk 群では治療により総死亡 が 22\%増加していた (ORs 1.22 CI, 1.06-1.42). 日本人のよ うに虚血性心疾患の罹患率, 死亡率が低い対象者に対し治 療を行う場合には，治療によるリスクを十分に考慮する必 要があると考えられる.

\section{III. 考 察}

高コレステロール血症は虚血性心疾患の危険因子であ るが，これまでみてきたように日本人の心筋梗塞の罹患率 は欧米の $1 / 5$ 以下であり, 日本の高コレステロール血症患 者全体を考えた場合, 薬物療法による冠動脈疾患の一次予 防効果は非常に小さく, 血清コレステロール值 $240 \mathrm{mg} / \mathrm{dl}$ の高コレステロール血症患者では, 男性で 376 人, 女性で は 1,550 人の患者を 5 年間治療して, 虚血性心疾患の発症 がようやく一人減少するにすぎない. 薬物療法の効果が少 ない対象者に薬物療法を行う場合には，治療効果より薬剤 の副作用の影響が上回ることがないか充分に考慮しなけれ ばならない.

スタチン系薬剤による 4S, WOS-COPS, CARE などの大 規模臨床試験では, これまで議論のあった癌, 事故, 自殺 とも, 全体として増加は認められなかったが, 一般的に臨 床試験の規模は治療効果を判定できる最小規模で計画され ているため, 副作用についての検討は臨床試験だけでは不 充分である. 従来の観察研究の報告では, 血清コレステ ロール值と総死亡の関係は男性でU 型, 女性では水平型と なっており，全体の死亡に対しては，むしろ低コレステ ロール血症の影響が大きい可能性がある，介入研究から も，虚血性心疾患の死亡率が 1,000 人年あたり 10 以下の集 団では, 全死亡が $22 \%$ 増加するというメタアナリシスの結 果が示されており, 高コレステロール血症の治療が心筋梗 塞を減らしても, 全体の死亡を増加させてしまう危険性も ある，そして，虚血性心疾患による死亡が少ない対象群に 対するスタチン系薬剤の投与が, 総死亡を増加させないと する根拠は現在のところない. 薬剤の副作用がその効果に かかわらず一定の確率で起こると仮定すると，スタチン系 薬剤の投与により年間一万人に一人重篤な副作用が発生す るならば, Fig. 1 で示したグラフから, 血清コレステロール 值 $240 \mathrm{mg} / \mathrm{dl}$ 以上であっても 40 歳未満の男性と 50 歳未満 の女性の集団では, 全体として薬剤の副作用が効果を上回
ることになる。

近年ライフスタイルの西欧化により, 高コレステロール 血症患者が増加しており, 日本においても虚血性心疾患が 増加しているという反論があるかもしれない. しかし, 今 回調べた範囲では，本邦における虚血性心疾患の罹患率が 高くなっているという根拠は乏しく, 都市部の男性職員で 増加傾向にあるというのが唯一の報告23) で, 1970 年代から 1980 年代にかけては, むしろ減少しているとの報告 ${ }^{24,25)} も$ ある. 久山町研究の第 1 集団 (1961-66) から第 3 集団 (1988-93) までの虚血性心疾患の罹患率の比較 ${ }^{26)}$ でも有意 な変化は認められていない。

高コレステロール血症患者における一次予防の治療必 要数の検討は, 日本人の虚血性心疾患の䍜患率に突然死を 加えた結果で行った. 日本人においては，24時間以内の突 然死の $54 \%$ が脳出血によるものであり, 冠動脈疾患による ものは $23 \%$ であったと報告 ${ }^{27)}$ れている. 英国では 6 時間 以内の突然死の $59 \%$ が冠動脈疾患によるもので, 脳出血等 による死亡は $4.3 \%$ との報告 ${ }^{28)}$ があり, 日本人では突然死の なかに含まれる虚血性心疾患の割合は欧米と比較して少な いと考えられ，治療必要数はより多い可能性がある.また， Hiroshima-Nagasaki Study では, 狭心症十心筋梗塞をエン ドポイントとしており，全体の虚血性心疾患の罹患率は， 男性で $3.1 / 1,000$ 人年, 女性で $1.3 / 1,000$ 人年と, 心筋梗塞の みをエンドポイントとした場合よりも罹患率が高く, 実際 の高脂血症治療薬による心筋梗塞の一次予防の効果はさら に小さいと考えられる。

高コレステロール血症に対するスタチン系薬剤の投与 は, 脳卒中のような他の動脈硬化性疾患を減少させるかも

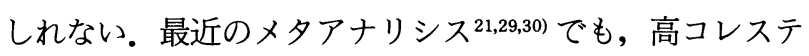
ロール血症患者へのスタチン系若剤の投与による脳卒中発 症の予防効果が示されている。しかし，本邦には皮質枝系 の梗塞が少なく, 穿通枝系脳梗塞の頻度が高いという特徵 があり ${ }^{311}$, また，これまでの日本人の脳卒中のコホート研 究でも, 高コレステロール血症を有意な危険因子としてい るものはなく, むしろ低コレステロール血症が脳出血の危 険因子となっており ${ }^{31}$, 欧米と比較して脳出血の多いわが 国においては，高コレステロール血症患者へのスタチン系 薬剤の投与が脳卒中発症を減少させるかどうかについて は，今後さらに検討する必要がある。

心筋梗塞の既往がある日本人の虚血性心疾患の再発率 については，49 カ月の追跡期間で $9.8 \%$ (24/1,000人年) と の報告があり ${ }^{32)}, 4 \mathrm{~S}$ study の結果から, スタチン系薬剤で 冠動脈疾患の発症が $34 \%$ 低下したと仮定すると, NNT は 22.7 人 $/ 5.4$ 年となり, 22.7 人の患者を約 5 年間治療すれば 心筋梗塞の発症を一人予防する効果が期待できる. 二次予 防を目的として高脂血症患者に pravastatin $10 \mathrm{mg}$ を投与し 
た場合には，心筋梗塞の発症を一人予防するために必要な 薬剤費は 837 万円となるが, 心筋梗塞の既往のない血清コ レステロール值 $240 \mathrm{mg} / \mathrm{dl}$ の高脂血症患者では, 心筋梗塞 の発症を一人予防するために, 男性で約 1 億 3,000 万円, 女 性では約 5 億 3,000 万円の薬剤費が必要となる. 現在の日 本人の虚血性心疾患の罹患率と薬剤の効果, 安全性, 医療 費の問題をあわせて考えると, 薬物療法は, 糖尿病, 高血 圧肥満, 喫煙, 家族歷などの他の危険因子を考慮のうえ, よ り高リスクのものに限って行うべきだと考えられる.

国際的な高コレステロール血症の診断, 治療のガイドラ インとして National Cholesterol Education Programの基 準 ${ }^{33)}$ があり, 昨年, 本邦に扔ける高脂血症診療ガイドライ ン14）発表された。しかし日本の高脂血疾患者の診断基 準, 治療適応基準を欧米とほほ同じに設定すると, 10 倍以 上効率が悪く, かつ全死亡増加の危険性もあるため, 高脂 血症患者の各種の基準は少なくとも欧米の基準よりは高め に設定すべきと考える.

日本人全体のコレステロール值の上昇は確かな事実で あり，これに対しまったく無策というわけにはいかない. しかし, 日本人の高コレステロール血症患者に対する薬物 療法による虚血性心疾患の一次予防効果には未解決の部分 が多く, 安全性を考えた場合, 薬物療法よりもコレステ ロール上昇の背景にあるライフスタイルに対する一般療 法，集団に対する介入に力を注ぐべきであろう.

\section{文献}

1) Scandinavian Simvastatin Survival Study Group : Baseline serum cholesterol and treatment effect in the Scandinavian Simvastatin Survival Study (4S). Lancet, 345: 1274-1275, 1995

2) Shepherd J, Cobbe SM, Ford I, Isles CG, Lorimer AR, MacFarlane PW, McKillop JH, and Packard CJ : Prevention of coronary heart disease with pravastatin in men with hypercholesterolemia. West of Scotland Coronary Prevention Study Group. N Engl J Med, 333: 1301-1307, 1995

3) Sacks FM, Pfeffer MA, Moye LA, Rouleau JL, Rutherford JD, Cole TG, Brown L, Warnica JW, Arnold JM, Wun CC, Davis BR, and Braunwald E, for the Cholesterol and Recurrent Events Trial Investigators: The effect of pravastatin on coronary events after myocardial infarction in patients with average cholesterol levels. N Eng J Med, 335: 1001-1009, 1996

4) Downs JR, Clearfield M, Weis S, Whitney E, Shapiro DR, Beere PA, Langendorfer A, Stein EA, Kruyer W, and Gotto AM : Primary prevention of acute coronary events with lovastatin in men and women with average cholesterol levels. Result of AFCAPS/TexCAPS. JAMA, 279: 1615-1622, 1998

5) Jacobs $D$, Blackburn $H$, Higgins $M$, Reed $D$, Iso $H$, McMillan G, Neaton J, Nelson J, Potter J, Rifkind B,
Rossouw J, Shekelle R, and Yusuf S : Report of the Conference on Low Blood Cholesterol: Mortality Associations. Circulation, 86 : 1046-1060, 1992

6) Shimamoto $T$, Iso $H$, Iida $M$, and Komachi $Y$ : Reserch activities of epidemiology in Japan Cardiovascular disease Epidemiology of Cerebrovascular disease: Epidemic in Japan. J Epidemiol, 6: S43-S47, 1996

7) Evidence-based medicine Working Group: Evidencebased medicine, a new aproach to teaching the practice of medicine. JAMA, 333 : 1301-1307, 1992

8) Laupacis A, Sackett DL, and Robert RS : An assessment of clinically useful measures of the consequences of treatment. New Engl J Med, 318: 1728-1733, 1988

9) 名郷直樹: 一人でできる Evidence-based medicine: 疑 問の定式化. JIM, 11: 414-419, 1997

10) 名郷直樹, 中村英治, 橋本 淳, 内堀充敏, 村田英和, 河合 徹, 平松敬人, 松島俊裕, 渡邊次夫, 丹羽治男, 白井量久：日常臨床における問題解決のための情報 源: 2. Cochrane Library. 月刊地域医学, 11 : 485-487, 1997

11) Tanaka H, Date $C$, Chen H, Nakayama $T$, Yokoyama $\mathrm{T}$, Yoshiie $\mathrm{N}$, Iwaoka $\mathrm{H}$, Iwaya $\mathrm{M}$, Zaman $\mathrm{MM}$, Yamaguchi M, Matsumura Y, Sugiyama M, Kushiro W, Ichimura T, Noji A, Chowdhury AH, Kim IS, Kwan TB, and Cho BM : Reserch activities of epidemiology in Japan Cardiovascular disease A brief review of epidemiological studies on ischemic heart disease in Japan. J Epidemiol, 6: S49-S59, 1996

12) Kodama K, Sasaki H, and Shimizu Y : Trend of coronary heart disease and its relationship to risk factors in a Japanese population: A 26-years follow up. Hiroshima/Nagasaki study. Jpn Clic J, 54 : 414-421, 1990

13) Committee of Principal Investigators: A co-operative trial in the primary prevention of ischemic heart disease using clofibrate. Report from the Committee of Principal Investigators. Br Heart J, 40: 1069-1118, 1978

14) 日本動脈硬化学会高脂血症診療ガイドライン検討委員 会: 高脂血症診療ガイドライン I. 成人高脂血症の 診断基準, 治療適応基準, 治療目標值. 動脈硬化, 25 : 1-34, 1997

15) The Pooling Project Research Group : Relationship of blood pressure, serum cholesterol, smoking habit, relative weight and ECG abnormalities to incidence of major coronary events: Final report of the pooling project. J Chron Dis, 31: 201-306, 1978

16) Iso $H$, Naito $Y$, Kitamura $A$, Sato $S$, Kiyama $M$, Takamaya Y, Iida M, Shimamoto T, Sankai T, and Komachi Y : Serum total cholesterol and mortality in a Japanese population. J Clin Epidemiol, 47 : 961-969, 1994

17) Muldoon MF, Manuck SB, and Matthews KA : Lowering cholesterol concentrations and mortality: a quantitative review of primary prevention trials. BMJ, 301 : 309-314, 1990

18) Smith GD, Song F, and Sheldon TA : Cholesterol lowering and mortality: the importance of considering initial level of risk. BMJ, 306: 1367-1373, 1993

19) Holme I: Cholesterol reduction and its impact on coronary artery disease and total mortality. Am-J- 
Cardiol, 76: 10C-17C, 1995

20) Holme I: Relationship between total mortality and cholesterol reduction as found by meta-regression analysis of randomized cholesterol-lowering trials. ControlClin-Trials, 17 : 13-22, 1996

21) Hebert PR, Gaziano JM, Chan KS, and Hennekens $\mathrm{CH}$ : Cholesterol lowering with statin drugs, risk of stroke, and total mortality. An overview of randomized trials. JAMA, 278 : 313-321, 1997

22) Gould AL, Rossouw JE, Santanello NC, Heyse JF, and Furberg $\mathrm{CD}$ : Cholesterol reduction yields clinical benefit. Impact of Statin Trials. Circulation, 97 : 946-952, 1998

23) Konishi $M$, Iso $H$, Iida $M$, Naito $Y$, Sato $S$, Komachi $Y$, Shimamoto T, Doi M, and Ito M: Trends for coronary heart diseaseand its risk factors in Japan : Epidemiologic and pathologic studies. Jpn Circ J, 54 : 428-435, 1990

24) Ueshima $H$, Tatara $K$, and Asakura $S$ : Declining mortality from ischemic heart disease and changes in coronary risk factors in Japan, 1956-1980. Am J Epidemiol, 125: 62-72, 1987

25) Tanaka H, Date C, Hayashi M, Mui K, Tsuchida M, Kurihara $\mathrm{H}$, and Kim DK : Trends in death and consultation rates of ischemic heart disease in Japan and the risk factors in a rural community. Jpn Cric J, $51: 306^{-}$ 313,1987

26) 清原 裕: 循環器疾患の発症率と危険因子一久山町
研究一. 循環器専門医, 5: 223-227, 1997

27) Omae $T$, Ueda $K$, Hasuo $Y$, and Tanaka $K$ : Sudden unexpected deaths in a Japanese community-Hisayama Study-. Jpn Cric J, 47: 554-561, 1983

28) Thomas AC, Knapman PA, Krikler DM, and Davies MJ : Community study of the cause of "natural" sudden death. BMJ, 297 : 1453-1456, 1988

29) Crouse JR III, Byington RP, Hoen HM, and Furberg $\mathrm{CD}$ : Reductase inhibitor monotherapy and stroke prevention. Arch-Intern-Med, 157: 1305-1310, 1997

30) Bucher HC, Griffith LE, and Guyatt GH : Effect of HMGcoA reductase inhibitors on stroke. A metaanalysis of randomized, controlled trials. Ann Intern Med, 128: 89-95, 1998

31) 上田一雄: 循環器疾患の危険因子, 本邦における特徵 とその変遷. 日循協誌，29: 57-67, 1994

32) Hosoda $S$, Iino $T$, Yasuda $H$, Takishima $T$, Ito $Y$, Kimata S, Mizuno Y, Inoue M, Kuzuya T, Kajiya F, and Nakamura $\mathbf{M}$ : Long-term follow-up of medically treated patients with coronary artery disease-I. Incidence of major cardiac events and its risk factors in Japanese with coronary artery disease. Jpn Circ J, 54 : 231-240, 1990

33) Summary of the second report of the National Cholesterol Education Program (NCEP) Expert panel on detection, evaluation, and treatment of high blood cholesterol in adults (Adult Treatment Panel II). JAMA, 269: 3015-3023, 1993 


\title{
Summary \\ Risk and benefit of cholesterol lowering drugs to prevent coronary heart disease in Japan
}

\author{
Atsushi Hashimoto, Tadao Goto, Mitsutoshi Uchibori, Eiji NaKamura, \\ Toru Kawal, Haruo Niwa, Kazuhisa ShIRAI, Toshihiro Matsushima, \\ Tsugio WatanaBe, and Naoki Nago
}

Department of Community and Family Medicine, Jichi Medical School, Japan

Background : The incidence of myocardial infarction among Japanese people appears to be far lower than that in Western countries. The efficacy of lowering the cholesterol level in a population with a low risk of coronary heart disease (CHD) is unclear.

Objective : We examined the risk and benefit of cholesterol lowering drugs to prevent CHD in Japanese patients with hypercholesterolemia.

Methods : Relevant publications (observational studies, randomized controlled trials and meta-analyses) were found using manual and computer-aided searches of the Cochrane Library and MEDLINE. The efficacy of cholesterol reduction has been quantified in the form of the number-needed-to-treat (NNT) to prevent a single incidence of myocardial infarction, according to the incidence of CHD in Japan and relative risk reduction (RRR) in a primary prevention trial. We examined the influence of cholesterol reduction on total mortality, and assessed the results of meta-analyses of interventional trials.
Results : In Japan, the average incidence of probable myocardial infarction is 0.99 per 1,000 for males, and 0.24 per 1,000 for females. In the United States and Northern European countries, the average incidence is 5.76 per 1,000 . If the RRR of CHD is $31 \%$, the NNT to prevent a single incidence of myocardial infarction is 376 persons per 5 years in Japanese men with hypercholesterolemia $(\mathrm{TC} \geqq 240 \mathrm{mg} / \mathrm{dl}$ ) and 1,550 persons per 5 years in women. The relationship between mortality and the serum total cholesterol level was U-shaped. One metaanalysis indicated that intervention in a low risk population (CHD mortality $<10 / 1,000$ person-years) increases the total mortality by $22 \%$.

Conclusion: The effect of cholesterol lowering drugs for primary prevention of myocardial infarction is lower than in Western countries, and drug intervention may increase the total mortality in Japan.

Key words : Hypercholesterolemia, Coronary heart disease, Mortality, Japan, Number needed to treat 